\title{
HUBUNGAN PENGETAHUAN REMAJA PUTRI USIA 13-15 TAHUN TENTANG DISMINORHOE DENGAN SIKAP DALAM PENANGANAN DISMINORHOE
}

\author{
Mimatun Nasihah*
}

*Dosen Program Studi Diploma III Kebidanan Universitas Islam Lamongan

\section{RINGKASAN}

Disminorhoe merupakan gejala yang dialami wanita muda saat menstruasi, sehingga memaksa wanita untuk istirahat. Pengetahuan tentang Disminorhoe sangat penting karena dengan pengetahuan baik dapat mempengaruhi sikap dalam mengatasi disminorhoe, sehingga aktivitasnya tidak terganggu. Tujuan penelitian untuk mengetahui hubungan antara pengetahuan remaja putri usia 13-15 tahun tentang Disminorhoe dengan sikap dalam penanganan Disminorhoe.

Desain penelitian adalah observasional analitik dengan pendekatan crosss secsional, dengan populasi 30 siswi kelas IX di SMP Ma'arif 7 Pucuk. Pengambilan sampel dengan tehnik simple random sampling dan didapat sampel 28 siswi. Variabel independen yakni pengetahuan remaja putri usia 13-15 tahun tentang Disminorhoe dan Variabel dependen yakni sikap dalam penanganan Disminorhoe. Pengambilan data menggunakan kuisioner selanjutnya dilakukan uji spearman dengan tingkat kemaknaan $\alpha=0,05$.

Hasil penelitian didapatkan $60,7 \%$ berpengetahuan kurang dan $53,6 \%$ mempunyai sikap kurang. Serta pada pengetahuan kurang sebagian besar dimanifestasikan pada sikap yang kurang yaitu 82,4\%. Berdasarkan hasil perhitungan dari SPSS Windows Versi 16,0 didapatkan hasil Spearman Rho $\mathrm{P}=0,000$ dimana $\mathrm{p}<0,05$ maka $\mathrm{H}_{0}$ ditolak, artinya terdapat hubungan antara pengetahuan remaja putri usia 13-15 tahun tentang Disminorhoe dengan sikap dalam penanganan Disminorhoe

Kurangnya pengetahuan tentang Disminorhoe mempengaruhi sikap dalam penanganan Disminorhoe.Sehingga diharapkan remaja putri meningkatkan pengetahuan tentang kesehatan reproduksi terutama masalah Disminorhoe dan penanganannya dengan cara mendapatkan informasi dari guru atau petugas kesehatan setempat.

Kata kunci : Pengetahuan, Sikap, Disminorhoe

\section{PENDAHULUAN}

Sekitar sepertiga dari
penduduk Indonesia terdiri dari
kelompok usia remaja yang perlu
dapat pembinaan dan pengawasan
serta pemberian informasi yang lebih
besar. Dalam usia remaja ini disebut
juga masa transisi dalam siklus
hidup, yaitu dari anak ke masa
dewasa yang penuh dengan masalah

dan tantangan dalam kehidupannya (Depkes RI; 2005).

Pada dasarnya Setiap wanita memiliki pengalaman menstruasi yang berbeda-beda. Sebagian wanita mendapatkan menstruasi tanpa keluhan, namun tidak sedikit dari mereka yang mendapatkan menstruasi disertai keluhan sehingga mengakibatkan 
ketidaknyamanan

berupa

Disminorhoe. Penyebab gangguan haid dapat karena kelainan biologik (organik atau disfungsional) atau dapat pula karena psikologik seperti keadaan-keadaan stress dan gangguan emosi atau gabungan biologik dan psikologik. Disminorhoe merupakan nyeri perut bagian bawah yang terkadang rasa nyeri tersebut meluas hingga ke pinggang, punggung bagian bawah dan paha. Pemeriksaannya harus dilakukan secara sistematis. Riwayat medis dan pemeriksaan fisik yang menyeluruh merupakan cara diagnostik yang berhubungan dengan asal Disminorhoe (A. Friedman Emanuel,1998:48).

Diagnostik tidak boleh berhenti pada jenis kelainan adanya penyakit atau kelainan yang menjadi dasar atau penyebabnya harus dicari, didiagnostik kemudian diterapi sesuai dengan keluhan..

Angka kejadian Disminorhoe di dunia sangat besar. Rata-rata lebih dari $50 \%$ perempuan di setiap dunia mengalaminya. Dari hasil penelitian tahun 2008, di Amerika persentase kejadian Disminorhoe sekitar 60\%, Swedia $72 \%$ pada usia 13-16 tahun dan di Indonesia 55\% wanita antara usia $15-20$ tahun. Penelitian di Amerika Serikat menyebutkan bahwa Disminorhoe dialami oleh 30\%-50\% pada wanita 2- 3 tahun setelah Menarche dan 10\%-15\% diantaranya kehilangan kesempatan kerja, mengganggu kegiatan belajar di sekolah dan kehidupan keluarga. Begitu pula angka kejadian Disminorhoe di Indonesia cukup tinggi, namun yang berobat ke pelayanan kesehatan sangatlah sedikit, yaitu hanya $1 \%-2 \%$ (Abidin, 2004).
Bahkan Angka kejadian Disminorhoe didaerah Jawa Barat sekitar $50-56 \%$ wanita mengalaminya, dan didaerah Jawa Timur sekitar 5565\% wanita mengalami Disminorhoe pada Usia 12-17 tahun (Abidin, 2004).

Menurut penelitian yang dilakukan oleh Rani tahun 2014 angka kejadian Disminorhoe di daerah Lamongan hampir mencapai $65 \%$ pada usia 12 - 18 tahun.

Berdasarkan survey awal yang dilakukan oleh peneliti di SMP Ma'arif 7 Pucuk, Kecamatan Pucuk, Kabupaten pada bulan Maret 2016 , dari 15 siswi yang sudah menstruasi yaitu terdapat 10 remaja putri pada usia 13-15 tahun (67\%) yang mengalami Disminorhoe saat haid. Dari data tersebut sebagian remaja putri masih banyak yang mengalami Disminorhoe, dan mereka tidak mengetahui sikap yang baik dalam mengatasinya. Sehingga menyebabkan kebanyakan siswi tidak mengikuti pelajaran dan harus tidur atau istirahat dirumah karena mengaami Disminorhoe.

Banyak faktor yang mempengaruhi remaja putri dalam mengatasi Disminorhoe diantaranya pengetahuan, lingkungan, motivasi, keluarga dan sebagai hasil penggunaan panca inderanya, yang berbeda sekali dengan kepercayaan atau beliefs, tahayul atau surerstitions dan peneranganpenerangan yang keliru atau missing information (Soejono, 2003: 5).

Seorang remaja yang mempunyai pengetahuan yang baik tentang Disminorhoe, maka dapat mempengaruhi remaja tersebut dalam mengatasi Disminorhoe. Dengan pengetahuan yang baik tentang Disminorhoe dan cara mengatasinya, sehingga remaja putri tidak perlu khawatir dan dapat 
mengatasi Disminorhoe tersebut serta aktivitasnya tidak terganggu. Dan apabila remaja putri berpengetahuan kurang tentang Disminorhoe, maka remaja putri tidak bisa mengatasi rasa nyeri tersebut sehingga tidak bisa melakukan aktivitas sehari-hari.

$$
\text { Lingkungan mempunyai }
$$

peran penting terhadap remaja antara lain tetangga dan teman sebaya yang memberikan informasi dan pengalaman tentang Disminorhoe, sehingga remaja akan merasa bahwa Disminorhoe adalah suatu kejadian normal dan tidak berbahaya. Lingkungan sekolah merupakan salah satu tempat memberikan informasi dan pengalaman tentang Disminorhoe. Pada lingkungan sekolah Guru merupakan tombak terpenting untuk memberikan gambaran ataupun wawasan terhadap muridnya, Guru ataupun Petugas setempat yang sudah dibekali pengetahuan tentang Disminorhoe, mempunyai kewajiban untuk memberikan informasi kepada remaja putri yang mengalami Disminorhoe. Misalnya dengan cara memberikan penyuluhan kepada remaja putri tentang tanda dan gejala Disminorhoe serta cara mengatasinya, seperti nasehat mengenai makanan sehat, istirahat yang cukup dan olah raga, kadang diperlukan psikoterapi. Akibat dari Disminorhoe tersebut muncul dalam bentuk rasa tidak nyaman ringan dan letih yang bersamaan dengan rasa nyeri dapat juga dijumpai rasa mual, muntah, sakit kepala, diare dan sebagainya. Sehingga memaksa wanita yang mengalami Disminorhoe untuk istirahat dan meninggalkan pekerjaan atau cara hidupnya seharihari untuk beberapa jam atau hari.
Salah satu cara yang dilakukan oleh remaja putri dalam sikap penanganan Disminorhoe dengan cara meningkatkan pengetahuan remaja putri tentang Disminorhoe dan memberi tahu cara mengatasinya, dengan pengetahuan baik remaja putri dapat mengatasi Disminorhoe tersebut sehingga aktivitasnya tidak terganggu. Kurangnya pengetahuan remaja putri tentang Disminorhoe membuat mereka tidak tahu apa yang harus dilakukan untuk mengatasi Disminorhoe. Upaya lain untuk mengurangi Disminorhoe antara lain kompres hangat di daerah perut atau punggung bagian bawah, olahraga yang terartur (terutama berjalan), istirahat cukup, mengurangi konsumsi garam dan memperbanyak mengkonsumsi buah-buahan dan sayuran, melakukan aktivitas seharihari yang ringan, mengurangi konsumsi kafein, terapi symtomatik lainnya dengan pemberian analgesik). (Taruna,2003).

Berdasarkan latar belakang di atas, maka peneliti tertarik untuk melakukan penelitian mengenai hubungan pengetahuan remaja putri usia 13-15 tahun tentang Disminorhoe dengan sikap dalam penaganan Disminorhoe.

\section{TUJUAN PENELITIAN}

Untuk mengetahui hubungan pengetahuan remaja putri usia 13-15 tahun tentang Disminorhoe dengan sikap dalam penanganan Disminorhoe.

\section{TINJAUAN PUSTAKA}

Menurut WHO, seseorang dikatakan remaja apabila telah mencapai usia $10-18$ tahun (Soetjiningsih, 2004:2). 
Menurut undang-undang No.4 tahun 1979 mengenai kesejahteraan anak, remaja adalah individu yang belum mencapai 21 tahun dan belum menikah (Soetjiningsih, 2004:1).

Masa remaja (adolesen) berasal dari bahasa latin adalescere yang berarti "bertumbuh" sepanjang fase perkembangan ini sejumlah masalah fisik, sosial dan psikologis bergabung untuk menciptakan karakteristik, perilaku dan kebutuhan yang unik (Bobak, 2004:827).

Dismenorhoe atau nyeri haid merupakan gejala, bukan penyakit. Gejalanya terasa nyeri di perut bagian bawah. Pada kasus Disminorhoe berat, nyeri terasa sampai seputaran panggul dan sisi dalam paha. Nyeri terutama pada hari pertama dan kedua menstruasi. Nyeri akan berkurang setelah keluar darah menstruasi

yang cukup banyak (Manuaba, 1999).

Disminorhoe adalah nyeri saat haid yang terasa di perut bagian bawah dan muncul sebelum, selama atau setelah menstruasi. Nyeri dapat bersifat kolik atau terus menerus. Disminorhoe timbul akibat kontraksi lapisan miometrium yang menampilkan satu atau lebih gejala mulai dari nyeri ringan hingga berat pada perut bagian bawah, daerah pantat dan sisi medial paha (Badziad, 2003).

Menstruasi menyebabkan gangguan psikologis atau fisik. Sesungguhnya mereka mungkin menderita berbagai subtype ketegangan sindrom premenstruasi. Perubahan suasana hati yang paling banyak dirasakan oleh wanita pada masa sebelum menstruasi tersebut datang dan mereda saat menstruasi tiba. Gejala fisik yang nampak misalnya kenaikan berat badan, buah dada yang nyeri, sakit kepala, migrain, pegal dan nyeri, gangguan pada kulit serta nafsu makan yang berlebihan. Gejala psikologis yang muncul misalnya ketegangan, rasa cepat marah, depresi, kelesuan, dan berkurangnya daya konsentrasi (Indriastuti, 2009).

Berdasarkan kajian teoritis yang ada, salah satu upaya mengurangi nyeri haid sebagai gangguan menstruasi yaitu membiasakan diri dengan perilaku sehat. Perilaku sehat pada saat menstruasi tidak akan terjadi begitu saja, tetapi merupakan sebuah proses yang dipelajari karena individu mengerti dampak positif atau negatif suatu perilaku yang terkait (Indriastuti, 2009).

Perilaku sehat pada saat menstruasi, akan menghindarkan wanita dari kanker rahim, merasa nyaman beraktivitas sehari-hari, percaya diri, bersemangat dan tidak malas-malasan lagi, tidak dijauhi teman karena bau badan amis dan tidak mempercayai mitos yang beredar di masyarakat karena sudah memahami kebenarannya.

Sedangkan apabila perilaku sehat tersebut tidak dilakukan maka remaja putri kurang peduli akan kebersihan alat reproduksinya, tidak menjaga penampilan dan kesehatan sewaktu menstruasi, dapat terkena kanker rahim, keputihan, mengurangi aktivitas saat menstruasi karena malas, kurang percaya diri, percaya akan mitos seputar menstruasi yang beredar di masyarakat (Indriastuti, 2009).

\section{HIPOTESIS}

Ada hubungan pengetahuan remaja putri usia 13-15 tahun tentang 
Disminorhoe dengan sikap dalam penanganan Disminorhoe,

\section{METODE PENELITIAN}

Jenis penelitian ini adalah Observasional. Analisa pada penelitian ini merupakan penelitian survey analitik yaitu penelitian yang mencoba menganalisa bagaimana dan mengapa fenomena kejadian itu terjadi, kemudian melakukan analisis korelasi antar variabel (Notoatmodjo, 2005).

Penelitian cross sectional akan mengukur atau mengumpulkan data mengenai pengetahuan remaja putri usia 13-15 tahun tentang Disminorhoe sebagai variabel bebas yang menjadi penyebab dan data sikap dalam penaganan Disminorhoe sebagai variabel terikat secara simultan dalam waktu yang bersamaan (Notoatmodjo, 2005)

\section{HASIL PENELITIAN}

\section{Distribusi Frekuensi Karateristik}

\section{Urutan Responden Dalam}

\section{Keluarga}

Tabel 1.1. Distribusi Frekuensi

Karateristik Urutan Responden Dalam Keluarga

\begin{tabular}{|c|c|c|c|}
\hline No & $\begin{array}{c}\text { Urutan } \\
\text { Responden Dalam } \\
\text { Keluarga }\end{array}$ & $\begin{array}{c}\text { Frek } \\
\text { uens } \\
\mathrm{i}\end{array}$ & $(\%)$ \\
\hline 1 & Anak ke-1 & 14 & 50,0 \\
2 & Anak ke-2 & 5 & 17,9 \\
3 & Anak ke-3 & 9 & 32,1 \\
\hline \multicolumn{2}{|c|}{ Jumlah } & 28 & 100 \\
\hline
\end{tabular}

Berdasarkan tabel di atas dari 28 responden siswi kelas IX di SMP Ma'arif 7 Pucuk, Kecamatan Pucuk, Kabupaten Lamongan tahun 2016 menunjukkan sebagian responden merupakan anak pertama yakni 14 responden $(50 \%)$ dan sebagian kecil responden merupakan anak ke-2 yakni 5 responden $(17,9 \%)$.

\section{Data Khusus}

Distribusi Frekuensi Pengetahuan Remaja Putri Usia 13-15 Tahun Tentang Disminorhoe

Tabel 1.2. Distribusi Frekuensi Pengetahuan Remaja Putri Usia 1315 Tahun Tentang Disminorhoe Pada Siswi Kelas IX

\begin{tabular}{|c|c|c|c|}
\hline No & $\begin{array}{l}\text { Pengetahuan } \\
\text { Remaja Putri } \\
13-15 \text { tahun }\end{array}$ & $\begin{array}{c}\text { Freku } \\
\text { ensi }\end{array}$ & $(\%)$ \\
\hline 1 & Kurang & 17 & 60,7 \\
\hline 2 & Cukup & 6 & 21,4 \\
\hline 3 & Baik & 5 & 17,9 \\
\hline \multicolumn{2}{|r|}{ Jumlah } & 28 & $100 \%$ \\
\hline
\end{tabular}

Dari tabel diatas dari 28 responden siswi kelas IX di SMP Ma'arif 7 Pucuk, Kecamatan Pucuk, Kabupaten Lamongan tahun 2016 menunjukkan sebagian besar responden dengan pengetahuan kurang tentang Disminorhoe yaitu 17 responden $(60,7 \%)$ dan sebagian kecil responden dengan pengetahuan baik yaitu 5 responden $(17,9 \%)$.

Distribusi Frekuensi Sikap Dalam Remaja Putri Usia 13-15 Tahun Penanganan Disminorhoe

Tabel 1.3. Distribusi Frekuensi Sikap Remaja Putri Usia 13-15 Tahun Dalam Penanganan Disminorhoe

\begin{tabular}{|c|c|c|c|}
\hline No & $\begin{array}{c}\text { Sikap Remaja } \\
\text { Putri }\end{array}$ & Frekuensi & $(\%)$ \\
\hline 1 & Kurang & 15 & 53,6 \\
2 & Cukup & 9 & 32,1 \\
3 & Baik & 4 & 14,3 \\
\hline \multicolumn{2}{|c|}{ Jumlah } & 28 & 100 \\
\hline
\end{tabular}

Dari tabel diatas dari 28 responden siswi kelas IX di SMP Ma'arif 7 Pucuk, Kecamatan Pucuk, Kabupaten Lamongan tahun 2016 
menunjukkan sebagian besar responden mempunyai sikap kurang dalam penangnanan Disminorhoe yaitu 15 responden $(53,6 \%)$ dan sebagian kecil responden mempunyai sikap baik dalam penanganan Disminorhoe yaitu 4 responden $(14,3 \%)$.

\section{PEMBAHASAN}

Dari tabel 1.1. menunjukkan sebagian besar siswi kelas IX di SMP Ma'arif 7 Pucuk mempunyai sikap yang kurang dalam penanganan Disminorhoe yaitu $53,6 \%$.

Sikap adalah merupakan suatu reaksi atau respon seseorang yang masih tertutup terhadap suatu stimulus atau objek (Soekidjo Notoatmodjo, 2003:130). Sikap secara nyata menunjukkan konotasi adanya kesesuaian dalam reaksi terhadap stimulus tertentu kehidupan sehari- hari adalah merupakan reaksi yang bersifat emosional terhadap stimulus sosial. Sikap belum merupakan suatu tindakan atau aktifitas, akan tetapi adalah merupakan predisposisi tindakan atau perilaku.

Upaya dalam penanganan Disminorhoe dapat dilakukan dengan melakukan sikap yang baik dalam penanganan Disminorhoe atau dengan melakukan prilaku yang positif seperti melakukan kompres hangat di daerah perut atau punggung bagian bawah, mandi dengan air hangat, olahraga yang terartur (terutama berjalan), istirahat cukup, mengurangi konsumsi garam dan minuman yang mengandung kafein, memperbanyak mengkonsumsi buah-buahan dan sayuran, melakukan aktivitas seharihari yang ringan, melakukan posisi knee chest, dan melakukan terapi symtomatik lainnya dengan pemberian analgesik). (Taruna,2003).

Dari hasil penelitian diatas dapat dipengaruhi oleh beberapa faktor yaitu : peran keluarga dalam menjelaskan Disminorhoe dalam sebuah haid, terpaparnya individu saat ada informasi, faktor sosial budaya, lingkungan, motivasi, pengetahuan individu dan juga petugas kesehatan. Kesemua faktor tersebut erat sekali kaitanya dalam pengambilan keputusan remaja dalam mengatasi Disminorhoe ataupun masalah yang lain selain masalah kesehatan reproduksi. Hal ini juga di dukung pernyataan dalam salah satu ciri sikap yang dikemukakan oleh Abu Ahmadi (2007:164-165) bahwa sikap itu adalah Personal - Societal Significance yang artinya sikap itu melibatkan hubungan antara seseorang dan orang lain dan juga antara orang dan barang atau situasi. Bisa diartikan disini bahwa barang dan situasi adalah mencakup keluarga, sosial budaya dan faktor lain yang berpengaruh.

Hubungan Pengetahuan Remaja Putri Usia 13-15 Tahun Tentang Disminorhoe Dengan Sikap Dalam Penanganan Disminorhoe

Dari Hasil uji Spearman's Rho dimana taraf signifikansi 5\% $(0,05)$ dengan nilai $\mathrm{p}$ hitung $=0,000$ dimana nilai $\mathrm{p}<\alpha$ maka $\mathrm{H}_{0}$ ditolak, artinya terdapat hubungan antara pengetahuan remaja putri tentang Disminorhoe dengan sikap dalam penanganan Disminorhoe, dari beberapa faktor yang mempengaruhi remaja putri dalam penanganan Disminorhoe seperti pengetahuan, lingkungan, motivasi, keluarga, dan juga petugas kesehatan dalam peningkatan pengetahuan tentang 
Disminorhoe yang pada selanjutnya akan mempengaruhi sikap si remaja putri tersebut dalam penanganan Disminorhoe.

Lingkungan adalah seluruh kondisi yang ada disekitar manusia yang dapat mempengaruhi perilaku yang mengakibatkan faktor internal (Nursalam, 2001: 125). Dengan adanya tetangga dan teman sebaya yang memberikan informasi dan pengalaman tentang Disminorhoe, sehingga remaja tersebut cenderung bersikap positif dan merasa bahwa Disminorhoe adalah suatu kejadian normal dan tidak berbahaya.

Motivasi mempunyai arti dorongan, yang berasal dari bahasa latin movere yang berarti mendorong atau menggerakkan. Motivasi adalah dorongan yang dimiliki seseorang atau individu untuk berperilaku atau beraktivitas dalam pencapaian tujuan atau kebutuhan (Tri Rusmi W, 1999: 112). Remaja putri yang mengalami Disminorhoe dengan motivasi yang tinggi maka dengan mudahnya mengambil sikap yang baik untuk mengurangi rasa sakit yang dialaminya. Dan terbukti kebanyakan responden sudah tau cara penanganan Disminorhoe.

Keluarga adalah unit terkecil dalam masyarakat yang terdiri atas kepala keluarga dan beberapa orang terkumpul di suatu tempat dibawah suatu atap dalam keadaan saling ketergantungan (Nasrul Effendy, 1998: 32). Dengan keluarga yang harmonis yang mau mendorong anaknya yang mengalami Disminorhoe untuk dapat mengatasi nyeri tersebut dan tetap memberikan arahan positif tentang cara penanganan Disminorhoe, sehingga kegiatan anak mereka tidak terganggu dan dapat melanjutkan aktifitasnya. .
Petugas kesehatan atau guru dalam lingkungan sekolah harus mampu menjalankan perannya dalam memberikan kesehatan, bentuk pendidikan kesehatan yang diberikan oleh petugas atau guru berupa penyuluhan kesehatan (Nasrul Effendy, 1998: 43). Para petugas atau guru setempat yang sudah dibekali pengetahuan tentang Disminorhoe, kurang memberikan informasi kepada remaja putri yang mengalami Disminorhoe sehingga sebagian besar responden mempunyai pengetahuan yang kurang tentang pengertian, tandagejala, serta cara penanganan Disminorhoe.

Soekidjo Notoatmodjo (2003: 122) mengemukakan bahwa perilaku atau tindakan seseorang dipengaruhi oleh pengetahuan dan sikap. Pada hakekatnya jika pengetahuan remaja putri ini baik, maka sikap remaja putri dalam penanganan Disminorhoe juga akan cenderung untuk mengambil sikap yang baik. Dalam kasus kali ini terlihat jelas bahwa pengetahuan yang kurang tentang Disminorhoe mempengaruhi sikap remaja putri dalam penanganan Disminorhoe.

Hal ini terbukti dengan pengetahuan remaja putri yang kurang maka remaja putri mempunyai sikap kurang dalam penanganan Disminorhoe. Hal ini mungkin dipengaruhi dari pengetahuan tentang Disminorhoe sehingga remaja putri tidak mengetahui bagaimana dalam mengatasi Disminorhoe.

Pada hakekatnya pada pengetahuan remaja putri ini baik, maka sikap remaja putri dalam penanganan Disminorhoe juga akan cenderung untuk mengambil sikap yang baik. Dalam kasus kali ini 
terlihat jelas bahwa pengetahuan yang kurang tentang Disminorhoe mempengaruhi sikap remaja putri dalam penanganan Disminorhoe. Oleh karena itu sebaiknya meningkatkan pengetahuan remaja putri tentang kesehatan reproduksi bukan tidak mungkin derajat kesehatan reproduksi bagi remaja putri di Indonesia bisa maksimal dan kesempatan remaja putri tersebut tidak terlalu besar dalam terpapar sumber informasi yang terlalu berisiko sehingga perilaku beresiko juga kita bisa minimalkan.

\section{SIMPULAN}

Sebagian besar Siswi kelas IX Di SMP Ma'arif 7 Pucuk mempunyai tingkat pengetahuan yang kurang tentang Disminorhoe.

Sebagian besar siswi kelas IX Di SMP Ma'arif 7 pucuk mempunyai sikap yang kurang dalam mengatasi Disminorhoe.

Ada hubungan antara pengetahuan remaja putri tentang Disminorhoe dengan sikap remaja dalam mengatasi Disminorhoe.

\section{SARAN}

1. Dari hasil penelitian diharapkan memberikan sumbangan bagi ilmu pengetahuan khususnya dalam hal pengetahuan tentang Disminorhoe. Dan sebagai sarana pembanding bagi dunia ilmu pengetahuan dalam memperkaya informasi tentang cara mengatasi Disminorhoe.

2. Diharapkan responden untuk lebih aktif mencari informasi yang berkaitan dengan kesehatan reporduksi remaja agar lebih mengerti dan tidak asal-asalan dalam mengambil sikap dalam mengatasi suatu permasalahan yang berhubungan dengan kesehatan reproduksi remaja.

3. Bagi Petugas kesehatan. Untuk lebih membudayakan penyuluhan tentang kesehatan reproduksi terutama pada remaja agar tidak terjerumus dalam hal-hal yang negatif.

4. Bagi Tempat penelitian. Dengan adanya hasil penelitian tersebut dapat digunakan untuk meningkatkan partisipasi dalam program dan sebagai data serta masukan yang dapat dipergunakan untuk mengetahui dan meningkatkan status kesehatan siswi, terutama mengurangi ketidak hadiran disekolah karena Disminorhoe.

\section{DAFTAR PUSTAKA}

Abidin, (2004), Nyeri Haid pada

Remaja.

http://perawatpskiatri.blogsp ot.com/2009/03/dismenore-

nyeri-padasaatmenstruasi.html. Akses 4 Maret 2016.

Abu Ahmadi, Haji (2007). Psikologi Sosial. Jakarta: PT. Rineka Cipta.

Admin. (2005). Menstruasi dan Penanganan Dismenorea. Cermin Dunia Kedokteran. No 133/ 2005.

Akatri, S. (1996). Penuntun Hidup Sehat Menurut Ilmu Kesehatan Modern. Surabaya:Airlangga University Press

Arikunto, Suharsimi. (2006). Prosedur Penelitian suatu Pendekatan Praktek. Jakarta: Rineka Cipta.

Badziad, A. (2003). Endokrinologi dan Ginekologi. Edisi ke-2. Jakarta: Media Aesculapius 
Fakultas Kedokteran

Universitas.

Bobak (2004). Buku Ajar

Keperawatan Maternitas.

Jakarta: EGC

Carey, C. S. (2001). Obstetri dan Ginekologi. Jakarta: Widya Medika.

DepKes RI (2005). Buku Saku Kesehatan Reproduksi Remaja. Jakarta

Hanifa Winkjosastro (2005). Ilmu Kandungan. Jakarta: YBPSP.

Hidayat, A.AA (2006). Riset Keperawatan dan Teknik Penulisan Ilmiah. Jakarta: Salemba Medika.

Hurlock, E.B. (2007). Psikologi Perkembangan Suatu Pendekatan Sepanjang Rentang Kehidupan. Jakarta: Erlangga.

Indriastuti, Dian Putri. (2009). Hubungan antara Pengetahuan Kesehatan Reproduksi dengan Perilaku Higienis Remaja Putri Pada saat Menstruasi. Fakultas Psikologi Universitas Muhammadiyah Surakarta. Surakarta..

Kartono, K. (2006). Psikologi Wanita Mengenal Gadis Remaja dan Wanita Dewasa.Jilid I. Bandung: Mandar Maju.

Mansjoer, A. (2001). Kapita Selekta Kedokteran. Edisi III. Jilid Pertama. Jakarta: Media Aesculapius.

Manuaba, Ida.Bagus.Gde. (1999). Memahami Reproduksi Wanita. Jakarta: Arcan.

Manuaba, Ida Bagus Gde (2001). Kapita Selekta Penatalaksanaan Rutin
Obstetri Ginekologi dan $K B$. Jakarta: EGC.

Mujaddid. (2004). Buku Ajar Penyakit Dalam. Jilid II. Edisi IV. Jakarta: Fakultas Kedokteran Universitas Indonesia.

Muliadi Nur. (2008). Sumber Pengetahuan. http://muliadinur.wordpress. com/2008/04/15/sumberpengetahuan. Akses 12 Maret 2016

Ngalim, Purwanto (2007). Psikologi Sosial. Jakarta: Rineka Cipta.

Notoatmodjo, Soekidjo. (2007). Promosi Kesehatan dan Ilmu Prelaku. Jakarta: Rineka Cipta.

Nursalam. (2008). Konsep dan Penerapan Metodologi Penelitian Ilmu Keperawatan: Jakarta: Salemba Medika.

Soetjiningsih (2004). Tumbuh Kembang Remaja dan Permasalahannya. Jakarta: Sagung Seto.

Sugiyono (2008). Metode Penelitian Kuantitatif, Kualitatif dan $R \& D . \quad$ Bandung: ALFABETA.

Taruna. (2003). Hipoterapi. http://www.medikaholistik.c om/medika.html?xmodule $=$ document_detail\&xid $=3$. akses 29 Maret 2016.

Winkjosastro, Hanifa (2005). Ilmu Kandungan. Jakarta: YBPSP 
